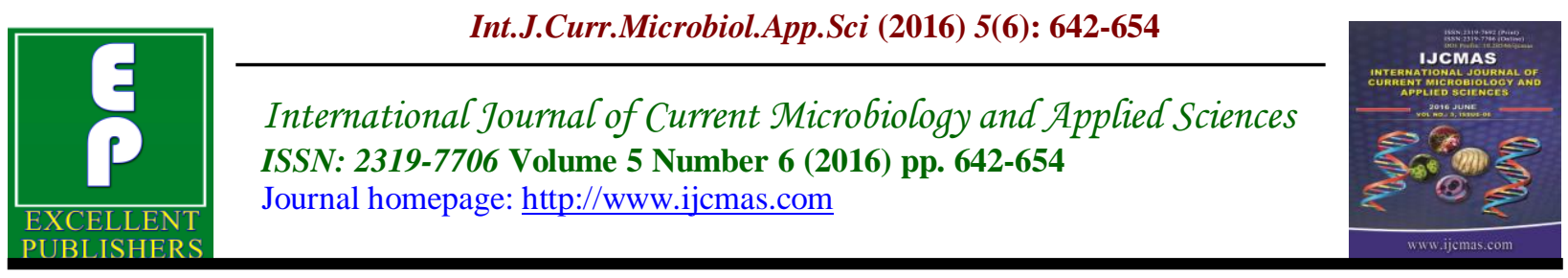

Original Research Article

http://dx.doi.org/10.20546/ijcmas.2016.506.070

\title{
HPTLC Finger Print Profile and Evaluation of in vitro Antimicrobial Activity of Mirabilis jalapa L. Flowers
}

\author{
K. Kalaivani and G. Prasanna* \\ PG and Research Department of Biochemistry, Sengamala Thayaar Educational Trust Women's \\ College, Sundarakkottai, Mannargudi, Thiruvarur Dt, Tamil Nadu, India \\ *Corresponding author
}

\begin{abstract}
A B S T R A C T
Keywords

Antimicrobial, flowers extract, HPTLC,

Mirabilis jalapa, phytochemical, quercetin.

\begin{tabular}{l}
\hline Article Info \\
\hline Accepted: \\
23 May 2016 \\
Available Online: \\
10 June 2016
\end{tabular}

The present study has been designed to carry out the phytochemical screening, HPTLC finger print profile and in vitro antimicrobial activity of aqueous flowers extract of Mirabilis jalapa. Preliminary phytochemical screening confirmed the presence of alkaloids, anthraquinones, glycosides, flavonoids, tannins, terpenes etc., In HPTLC analysis, quercetin bands were identified in sample chromatogram ( 5 and $10 \mu \mathrm{l}$ ) which was confirmed by the chromatogram obtained from the standard quercetin and by comparing retention factors of quercetin (Rf - 0.51) value is from sample and standard solution. In vitro antimicrobial activity of plant extract ( 50,100 and $150 \mu \mathrm{g} / \mathrm{ml}$ ) was also performed by using disc diffusion method against the pathogenic bacteria such as Staphylococcus aureus, Pseudomonas aeruginosa, Bacillus subtilis, and E.coli, pathogenic fungi such as Candida albicans and Trichoderma viride. $150 \mu \mathrm{g}$ of aqueous flowers extract was active against both the bacterial and fungal species. Standard antibiotics gentamicin, amphotericin-B were also performed for antibacterial and antifungal activity respectively. The results of our study indicated that flavonoid quercetin is present in the plant extract which may responsible for potent antimicrobial activity against pathogenic microorganisms.
\end{abstract}

\section{Introduction}

Human beings have used plants for the treatment of diverse ailments for thousands of years (Sofowara, 1982; Hill, 1989). According to the World Health Organization, most populations still rely on traditional medicines for their psychological and physical health requirements (Rabe and Van Stoden, 2000), since they cannot afford the products of Western pharmaceutical industries together with their side effects and lack of healthcare facilities (Griggs et al.,
2001). Rural areas of many developing countries still rely on traditional medicine for their primary health care needs and have found a place in day-to-day life. These medicines are relatively safer and cheaper than synthetic or modern medicine (Iwu et al., 1999; Idu et al., 2007; Mann et al., 2008; Ammara et al., 2009).

In many parts of the world, medicinal plants have been used for its antibacterial, antifungal and antiviral activities for 
hundreds of years (Ali et al., 1998; Barbour et al., 2004; Yasunaka et al., 2005). Researchers are increasingly turning their attention to natural products and looking for new leads to develop better drugs against cancer, as well as viral and microbial infections (Ibrahim, 1997; Koshy et al., 2009). Several synthetic antibiotics are employed in the treatment of infections and communicable diseases. The harmful microorganisms can be controlled with drugs and this has resulted in the emergence of multiple drug resistant bacteria and it has created alarming clinical situations in the treatment of infections

During the last two decades, the development of drug resistance as well as the appearance of undesirable side effects of certain antibiotics (Okemi et al., 2003) has led to the search new antimicrobial agents mainly among plant extracts with the goal to discover new chemical structures which over come to above disadvantages (Bouamama et al., 2006). Current research on natural molecule and products primarily focuses on plants since they can be sourced more easily and be selected based on their ethno medicinal uses (Arora et al., 2007). The traditional and folk medicinal system uses the plant products for the treatment of various infectious diseases. In recent times, plants are being extensively explored for harboring medicinal properties. Keeping in view the above states, the present study deal with the phytochemical investigation, development of HPTLC finger printing and in vitro antimicrobial activity of aqueous flowers extract of Mirabilis jalapa $\mathrm{L}$.

Mirabilis jalapa (Family: Nyctainaceae) is a small glabrous herb grows up to $0.5 \mathrm{~m}$ in height, with succulent stems. Flowers are tubular, cluster, funnel-shaped, simple or double, fragrant, white, yellow, pink or purple. An individual flower opens for one night in the early evening, the exact time depending on temperature and relative humidity, and closely the next morning. An individual plant produces between 25 and 75 flowers in one flowering season. The seeds are olive, brown or black in color. The root system consists of a fairly thickened and tuberous up to $1 \mathrm{~mm}$ high, stem swollen at nodes (Muthumani et al., 2009).

\section{Phytoconstituents}

Roots, seeds and leaves are the reported plant part used from ancient times. The major phytoconstituents found in Mirabilis jalapa are the rotenoids (mirabijalones A- D boeravinones $\mathrm{C}$ and $\mathrm{F}$ ), an isoquinoline derivate as well as terpenoids, steroids, phenolic compounds, alanine, alphaamyrine, arabinose, beta-amyrins, oleanolic acid, trophan, stigmasterols, betasistosterol, beta-D -glycoside, urolic acid, mirablisoic acid, mirabalisol, trigonellin and antiviral protein, C-methylabron isoflavone, tartaric acid, betanin, brassicasterol, betalanic acid. Mirabilis jalapa is rich in many active compounds of which, particular interest to researchers is a group of amino acid proteins, called Mirabilis antiviral protein.

\section{Traditional Uses}

Mirabilis jalapa $L$ is known as a very bioactive plant and used in various diseases as folklore medicine. The leaves are used as traditional folk medicine in the south of Brazil to treat inflammatory and painful diseases and as a laxative. In traditional medicine, Mirabilis jalapa is widely used as antidysenteric, antiparasitic, carminative, digestive stimulant, tonic, vermifuge, wound healer. Seeds are used as cathartic. This plant contains bio active components like trigonellin as a purgative and rotenoids used as an antispasmodic. In Ayurveda, this plant used for boils, inflammations, constipation, 
diabetes, urinary disorders. Dried flowers used as a snuff for headaches, fungal infection and root decoction is used to wash wounds, treat skin afflictions as leprosy (Kiran kumar et al., 2010). It is also used a remedy for the kidney stones and gall bladder (Vardhana, 2008).

\section{Materials and Methods}

\section{Collection of Plant Materials}

The mature flowers of Mirabilis jalapa were collected from Koothanallur at Thiruvarur District in Tamil Nadu. Then the plant flowers were identified, authenticated and the specimen was deposited in the Department of Biochemistry, S.T.E.T. Women's College, Mannargudi, Thiruvarur District, Tamil Nadu.. The plant material was cleaned, and then they were shade dried. The dried plant materials were coarsely powdered using a mechanical grinder. The powder was stored in air light resistant container for further analysis.

\section{Preparation of Plant Extract}

$100 \mathrm{~g}$ of the flower powder was macerated using $500 \mathrm{ml}$ of distilled water for 8-10 hours. The extract was filtered through what man No. 1 filter paper to remove all extractable matter, including cellular materials and other constitutions that are insoluble in the extraction solvent. The entire extract was concentrated to dryness using rotary flash evaporator under reduced pressure. The dried extract was used for further analysis.

\section{Preliminary Phytochemical Screening}

The flowers extract was subjected to preliminary phytochemical investigations to determine the different phytoconstituents using standard procedures (Harborne, 1984).

\section{HPTLC Finger Print Profile}

About $1 \mathrm{mg}$ of the extract of the Mirabilis jalapa L. was taken and dissolved in respective solvent and the volume was up to $1 \mathrm{ml}$ in a standard flask $(1000 \mu \mathrm{g} / \mathrm{ml})$. This solution was used as test solution for HPTLC analysis. Silica gel 60 F254 and HPTLC aluminum sheets were used as adsorbent (stationary phase). 5 and $10 \mu \mathrm{L}$ of the above test solution and $2 \mu \mathrm{L}$ of a standard solution (quercetin) were loaded on HPTLC aluminum sheets as different tracks in the form of $6 \mathrm{~mm}$ wide bands by using a CAMAG semi-automatic Linom at 5 spotters at a distance of $12 \mathrm{~mm}$. Nitrogen gas was also supplied for simultaneous drying of bands.

The samples-loaded plate was kept in TLC twin trough developing chamber (after saturation with solvent vapor) with mobile phase toluene: ethyl acetate: formic acid $(5: 4: 1)$. The developed plates were then dried and scanned using a TLC scanner 3 with Wincats software under $364 \mathrm{~nm}$. All plates were visualized directly after drying and a fingerprint profile was photo documented using a CAMAG Reporter- 3 under $254 \mathrm{~nm}$ and $366 \mathrm{~nm}$ in UV and visible light. The peak table, peak display and peak densitogram were recorded (Srivastava, 2011; Sethi, 2013).

\section{Antimicrobial Activity}

\section{Selection of Microorganism}

Totally six pathogenic microorganism such as Staphylococcus aureus, Streptococcus pyogenes, Escherichia coli, Bacillius subtilis and Aspergillus niger, Trichoderma viride were selected for antimicrobial activity. The pure microbial culture were collected from Centre for Life Science Research, Thanjavur, and inoculated in the tube using inoculation needles or loops. The tubes were 
incubated at $37^{\circ} \mathrm{C}$ for 24 hours.

\section{Screening of Antimicrobial Activity by Agar Well Diffusion Method}

The antibacterial and antifungal activities of flowers extract of Mirabilis jalapa was tested against the selected bacterial and fungal strains. Nutrient agar medium (for bacteria) and potato dextrose agar medium (for fungi) were prepared by sterilizing them with the use of autoclave at $121{ }^{\circ} \mathrm{C}$ and 15 lbs pressure for 15 minutes; petriplates were also sterilized using autoclave. After sterilization, about $25 \mathrm{ml}$ the cooled medium was poured into petriplates and allowed to solidify in a laminar air flow chamber. After solidification, the test bacterial and fungal cultures were spread by using a sterile cotton swab over the plate by spread plate technique. Well of $5 \mathrm{~mm}$ size made in the agar plates with the help of sterile cork borer, each well were loaded with different concentration $(50,100,150 \mu \mathrm{l})$ of aqueous flowers extract of Mirabilis jalapa using micropipette and allowed to diffuse at room temperature for 2 hours. The antibiotics gentamicin and amphotericin B were used as standard for antibacterial and antifungal activity respectively. All the plates were incubated at $37^{\circ} \mathrm{C}$ for 24 hours. After incubation, the plates were observed for formation of clear inhibition zone around the well indicated the antibacterial and antifungal activities. The zone of inhibition was calculated by measuring the diameter of the inhibition zone around the well (Bauer et al., 1966; Perez et al., 1990)

\section{Statistical Analysis}

Values of antimicrobial activities were expressed as mean value of triplicate \pm S.D

\section{Results and Discussion}

In the present study, phytochemical screening, HPTLC finger printing analysis and in vitro antimicrobial activity were carried out in aqueous flowers extract of Mirabilis jalapa. The obtained results were recorded and tabulated.

\section{Preliminary Phytochemical Screening}

Table 1 shows the phytoconstituents of aqueous extract of Mirabilis jalapa flowers. Results revealed the presence of alkaloids, anthroquinones, glycosides, flavonoids, steroids, tannins, terpenes and absence of carbohydrate, saponins, and proteins.

\section{HPTLC Finger Printing Analysis}

HPTLC finger prints of aqueous flowers extract $(5 \mu 1$ and $10 \mu 1)$ of Mirabilis jalapa were done by using selected solvent system toluene: ethyl acetate: formic acid (5:4:1), visualized under UV $254 \mathrm{~nm}$ before derivatization. The peaks obtained were analyzed and the $\mathrm{Rf}$ value was compared to the standard. The presence of a specific peak for quercetin at $\mathrm{Rf} 0.51$ was recorded and considered as a positive result for quercetin (fig. 2, $3 \&$ table 2, 3,4).

\section{Antimicrobial Activity}

Antimicrobial activity was performed in aqueous flowers extract of Mirabilis jalapa against pathogenic bacteria such as Staphylococcus aureus, Pseudomonas aeruginosa, Bacillus subtilis, and E.coli and pathogenic fungi such as Candida albicans, and Trichoderma viride by disc diffusion method.

\section{Antibacterial Activity}

The anti bacterial activities of plant extract against tested bacterial pathogen were represented in table 5 . Three different concentrations $(50,100$, and $150 \mu \mathrm{g} / \mathrm{ml})$ of plant extracts were selected, all are found to 
be active against both gram positive and gram negative bacterial strains. Maximum zone of inhibition was observed in $150 \mu \mathrm{g}$ of plant extract against Pseudomonas aeruginosa $(56 \mathrm{~mm})$ followed by Bacillus subtilis $(36 \mathrm{~mm})$, E.coli $(28 \mathrm{~mm})$ and Staphylococcus aureus $(27 \mathrm{~mm})$. Moderate results were obtained in $100 \mu \mathrm{g}$ of plant extract against Pseudomonas aeruginosa (42.5 mm) followed by Bacillus subtilis (27 $\mathrm{mm})$, Staphylococcus aureus (26 $\mathrm{mm})$ and E.coli $(25 \mathrm{~mm})$ and least activity was observed in $50 \mu \mathrm{g}$ of plant extract against Pseudomonas aeruginosa $(42.4 \mathrm{~mm})$ followed by Bacillus subtilis $(26 \mathrm{~mm})$ and E.coli $(25 \mathrm{~mm})$ and Staphylococcus aureus (26 mm). Antibacterial activity of standard antibiotic gentamicin was also performed and the zone of inhibition were $63 \mathrm{~mm}$ for E.coli, $68.8 \mathrm{~mm}$ for P. aeruginosa, $46.5 \mathrm{~mm}$ for B. subtilis and $58.2 \mathrm{~mm}$ for S.aureus. When compared with antibiotic, plant extract exhibited moderate antibacterial activity against all tested pathogenic bacteria (fig.7).

\section{Antifungal Activity}

In the present investigation, antifungal activities of three different concentration of $(50,100,150 \mu \mathrm{g})$ flower extract of Mirabilis jalapa have been evaluated in vitro against fungal strains Trichoderma viride and Candida albicans (table 5, fig 8). Maximum zone of inhibition was observed in $150 \mu \mathrm{g}$ of plant extract against Candida albicans (33.5 $\mathrm{mm}$ ) followed by Trichoderma viride (25.5 $\mathrm{mm})$. Moderated results were obtained in $100 \mu \mathrm{g}$ of plant extract in the order of Candida albicans and Trichoderma viride and their zone of inhibition in mm were 32.5 and 27 respectively. Similarly, least result of 25.5 and $33.5 \mathrm{~mm}$ was observed in $50 \mu \mathrm{g}$ of plant extract against Candida albicans and Trichoderma viride. Standard antibiotic amphotericin-B was also performed for its antifungal activity and the inhibitory zone were $30 \mathrm{~mm}$ and $37.3 \mathrm{~mm}$ for Trichoderma viride and Candida albicans respectively. When compared with standard, plant extract exhibited moderate antifungal activity against all tested pathogenic fungi.

In the recent years, research on medicinal plants has attracted a lot of attention globally. Large body of evidence has accumulated to demonstrate the promising potential of medicinal plants used in various traditional, complementary and alternate systems of treatment of human diseases. Phytochemicals are chemical compounds synthesized during the various metabolic processes. Various phytochemicals possess a variety of pharmacological activities. These chemicals are often called secondary metabolites. Some of these are found to have in vitro antimicrobial properties (Dahanukar et al., 2000; Cowan, 1999) and serve as plant defence mechanisms against pathogenic organisms. These compounds are classified as phenols, quinines, flavonoids, tannins, alkaloids, glycosides and polysaccharides.

In the present study, result of preliminary phytochemical analysis revealed the presence of alkaloids, anthroquinones, glycosides, flavonoids, steroids, tannins, terpenes and absence of carbohydrate, saponins, and proteins. Flavonoids like quercetin and catechin are becoming the subject of medical research (Gupta et al., 2012). Flavonoids interfere with specific intracellular or surface enzymes and many bacterial virulence factors such as toxins, enzymes and signal receptors (Cushnie, 2011).

HPTLC, High Performance Thin Layer Chromatography, is the most recent evolution of planar chromatography and has been specifically tailored for analysis of 
natural products (Pharmacopéè Francaise, 1965; Reich and Schibli, 2007). It is one of the modern sophisticated techniques that can be used for evaluating the potency, authenticity, quality and purity of crude drugs (Mamatha, 2011). It offers better resolution, and estimation of active constituents can be done with reasonable accuracy in a shorter time (Syed et al., 2013).

In the present study, HPTLC finger printing profile of plant extract was performed at the wave length of $254 \mathrm{~nm}$ in TLC scanner. The result gave a sharp and well -defined band with $\mathrm{Rf}=0.51$ for quercetin. This showed the presence of the bioactive compound flavonoid. The identity of the quercetin bands in sample chromatograms was confirmed by the chromatogram obtained from the sample with that obtained from the reference standard solution (Sachin Rakesh et al., 2009). Quercetin is a flavonol, one of the most abundant natural flavonoid, being extensively found in many plants. It is of great interest because of its pharmacological function (Walid et al., 2015).

Antimicrobial activity can be regarded as a very important study, particularly at this specific period of human history due to bacterial resistance that is constantly imposing new scientific challenges. In spite of great development in drug therapy, infectious diseases remain as the most common reasons for mortality in many developing countries. Resistance to antimicrobial agents has become an increasingly important and pressing global problem. According to the WHO, plants are a source of compounds that have the ability to combat disease.

Table.1 Preliminary phytochemical screening of Mirabilis jalapa flowers

\begin{tabular}{|l|l|c|}
\hline S.No. & Phytochemicals & Results \\
\hline 1. & Alkaloids & + \\
\hline 2. & Anthraquinones & + \\
\hline 3. & Carbohydrates & - \\
\hline 4. & Glycosides & + \\
\hline 5. & Flavonoids & + \\
\hline 6. & Saponins & - \\
\hline 7. & Steroids & + \\
\hline 8. & Tannins & + \\
\hline 9. & Terpenes & - \\
\hline 10. & Protein & + \\
\hline \multicolumn{2}{|c|}{+ - indicate presence: - indicate absent } \\
\hline
\end{tabular}

Table. 2 HPTLC finger print profile for standard $(2 \mu \mathrm{l})$

\begin{tabular}{|ccccccccccc|}
\hline Peak & $\begin{array}{c}\text { Start } \\
\text { Rf }\end{array}$ & $\begin{array}{c}\text { Start } \\
\text { Height }\end{array}$ & $\begin{array}{c}\text { Max } \\
\text { Rf }\end{array}$ & $\begin{array}{c}\text { Max } \\
\text { Height }\end{array}$ & $\begin{array}{c}\text { Height } \\
\text { \% }\end{array}$ & $\begin{array}{c}\text { End } \\
\text { Rf }\end{array}$ & $\begin{array}{c}\text { End } \\
\text { Height }\end{array}$ & Area & $\begin{array}{c}\text { Area } \\
\%\end{array}$ & $\begin{array}{c}\text { Assigned } \\
\text { Substance }\end{array}$ \\
\hline 1 & $\mathbf{0 . 4 5}$ & $\mathbf{6 . 4}$ & $\mathbf{0 . 5 1}$ & $\mathbf{4 6 8 . 1}$ & $\mathbf{1 0 0 . 0 0}$ & $\mathbf{0 . 5 5}$ & $\mathbf{0 . 1}$ & $\mathbf{9 6 7 1 . 8}$ & $\mathbf{1 0 0 . 0 0}$ & Quercetin \\
\end{tabular}


Table.3 HPTLC finger print profile for sample $(5 \mu 1)$

\begin{tabular}{|ccccccccccc|}
\hline peak & $\begin{array}{c}\text { Start } \\
\text { Rf }\end{array}$ & $\begin{array}{c}\text { Start } \\
\text { Height }\end{array}$ & $\begin{array}{c}\text { Max } \\
\text { Rf }\end{array}$ & $\begin{array}{c}\text { Max } \\
\text { Height }\end{array}$ & $\begin{array}{c}\text { Height } \\
\mathbf{\%}\end{array}$ & $\begin{array}{c}\text { End } \\
\text { Rf }\end{array}$ & $\begin{array}{c}\text { End } \\
\text { Height }\end{array}$ & Area & $\begin{array}{c}\text { Area } \\
\text { \% }\end{array}$ & $\begin{array}{c}\text { Assigned } \\
\text { Substance }\end{array}$ \\
\hline $\mathbf{1}$ & 0.03 & 0.1 & 0.07 & 98.4 & 49.39 & 0.11 & 0.1 & 2169.1 & 43.94 & Unknown \\
\hline $\mathbf{2}$ & 0.14 & 0.1 & 0.21 & 50.9 & 25.54 & 0.24 & 3.7 & 1533.5 & 31.07 & Unknown \\
\hline $\mathbf{3}$ & 0.24 & 3.8 & 0.27 & 15.8 & 7.91 & 0.32 & 0.1 & 445.3 & 9.02 & Unknown \\
\hline $\mathbf{4}$ & 0.40 & 5.5 & 0.43 & 11.1 & 5.56 & 0.44 & 10.0 & 232.5 & 4.71 & Unknown \\
\hline $\mathbf{5}$ & $\mathbf{0 . 4 7}$ & $\mathbf{1 1 . 3}$ & $\mathbf{0 . 5 0}$ & $\mathbf{2 3 . 1}$ & $\mathbf{1 1 . 6 0}$ & $\mathbf{0 . 5 3}$ & $\mathbf{0 . 1}$ & $\mathbf{5 5 5 . 9}$ & $\mathbf{1 1 . 2 6}$ & Quercetin \\
\hline
\end{tabular}

Table.4 HPTLC finger print profile for sample $(10 \mu \mathrm{l})$

\begin{tabular}{|ccccccccccc|}
\hline peak & $\begin{array}{c}\text { Start } \\
\text { Rf }\end{array}$ & $\begin{array}{c}\text { Start } \\
\text { Height }\end{array}$ & $\begin{array}{c}\text { Max } \\
\text { Rf }\end{array}$ & $\begin{array}{c}\text { Max } \\
\text { Height }\end{array}$ & $\begin{array}{c}\text { Height } \\
\text { \% }\end{array}$ & $\begin{array}{c}\text { End } \\
\text { Rf }\end{array}$ & $\begin{array}{c}\text { End } \\
\text { Height }\end{array}$ & Area & $\begin{array}{c}\text { Area } \\
\text { \% }\end{array}$ & $\begin{array}{c}\text { Assigned } \\
\text { Substance }\end{array}$ \\
\hline $\mathbf{1}$ & 0.03 & 4.2 & 0.07 & 123.0 & 34.87 & 0.10 & 0.4 & 3343.6 & 34.12 & unknown \\
\hline $\mathbf{2}$ & 0.14 & 0.2 & 0.21 & 91.7 & 26.00 & 0.24 & 12.5 & 2975.5 & 30.36 & unknown \\
\hline $\mathbf{3}$ & 0.24 & 12.9 & 0.27 & 32.1 & 9.11 & 0.33 & 0.0 & 1046.8 & 10.68 & unknown \\
\hline $\mathbf{4}$ & 0.39 & 3.1 & 0.45 & 17.4 & 4.92 & 0.43 & 16.5 & 627.5 & 6.40 & unknown \\
\hline $\mathbf{5}$ & $\mathbf{0 . 4 7}$ & $\mathbf{1 6 . 5}$ & $\mathbf{0 . 5 0}$ & $\mathbf{2 7 . 3}$ & $\mathbf{7 . 7 3}$ & $\mathbf{0 . 5 1}$ & $\mathbf{2 5 . 7}$ & $\mathbf{6 5 5 . 3}$ & $\mathbf{6 . 6 9}$ & Quercetin \\
\hline $\mathbf{6}$ & 0.51 & 25.9 & 0.53 & 38.0 & 10.77 & 0.57 & 1.8 & 930.5 & 9.49 & unknown \\
\hline $\mathbf{7}$ & 0.96 & 0.2 & 0.98 & 23.3 & 6.60 & 0.99 & 17.2 & 221.2 & 2.26 & unknown \\
\hline
\end{tabular}

Table.5 Antibacterial activity of aqueous extract of Mirabilis jalapa L. flowers

\begin{tabular}{|c|c|c|c|c|c|}
\hline \multirow[t]{3}{*}{ S. No. } & \multirow[t]{3}{*}{ Bacterial strains } & \multicolumn{4}{|c|}{ Zone of Inhibition ( $\mathrm{mm}$ in diameter) } \\
\hline & & \multicolumn{3}{|c|}{ Plant extract $(\mu \mathrm{g} / \mathrm{ml})$} & \multirow{2}{*}{$\begin{array}{l}\text { Standard } \\
\text { antibiotic }\end{array}$} \\
\hline & & $50 \mu \mathrm{g} / \mathrm{ml}$ & $100 \mu \mathrm{g} / \mathrm{ml}$ & $150 \mu \mathrm{g} / \mathrm{ml}$ & \\
\hline 1 & Escherichia coli & $25.5 \pm 0.5$ & $25 \pm 0.28$ & $28 \pm 0.76$ & $63 \pm 0.36$ \\
\hline 2 & Pseudomonas aeruginosa & $42.5 \pm 1.04$ & $42.5 \pm 1.25$ & $56 \pm 0.76$ & $68.8 \pm 0.11$ \\
\hline 3 & Bacillus subtilis & $26 \pm 1.60$ & $27 \pm 2.17$ & $36 \pm 0.86$ & $46.5 \pm 0.5$ \\
\hline 4 & Staphylococcus aureus & $24 \pm 1.32$ & $26 \pm 2.46$ & $27 \pm 1.32$ & $58.2 \pm 97.4$ \\
\hline
\end{tabular}

All values are expressed as mean \pm SEM for three determinations. 
Table.6 Antifungal activity of aqueous extract of Mirabilis Jalapa L.flowers

\begin{tabular}{|l|l|l|l|l|l|}
\hline \multirow{3}{*}{$\begin{array}{c}\text { S. } \\
\text { No. }\end{array}$} & \multirow{2}{*}{ Fungal strains } & \multicolumn{4}{|c|}{ Zone of Inhibition $(\mathbf{m m}$ in diameter) } \\
\cline { 3 - 5 } & & \multicolumn{3}{|c|}{ Plant extract $(\boldsymbol{\mu g} / \mathbf{m l})$} & $\begin{array}{c}\text { Standard } \\
\text { antibiotic }\end{array}$ \\
\cline { 3 - 6 } & & $\mathbf{5 0} \boldsymbol{\mu g} / \mathbf{m l}$ & $\mathbf{1 0 0} \boldsymbol{\mu g} / \mathbf{m l}$ & $\mathbf{1 5 0} \boldsymbol{\mu g} / \mathbf{m l}$ & $30 \pm 0.25$ \\
\hline $\mathbf{1}$ & Trichoderma viride & $19.5 \pm 0.5$ & $27 \pm 1.32$ & $25.5 \pm 0.86$ & $37.3 \pm 0.40$ \\
\hline $\mathbf{2}$ & Candida albicans & $26.5 \pm 0.76$ & $32.5 \pm 1.60$ & $33.5 \pm 1.04$ & 3 \\
\hline
\end{tabular}

All values are expressed as mean \pm SEM for three determinations.

Fig.1 HPTLC finger print profile

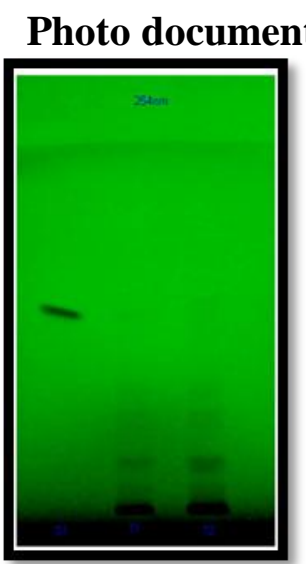

S1 S2 S3

AT $254 \mathrm{~nm}$

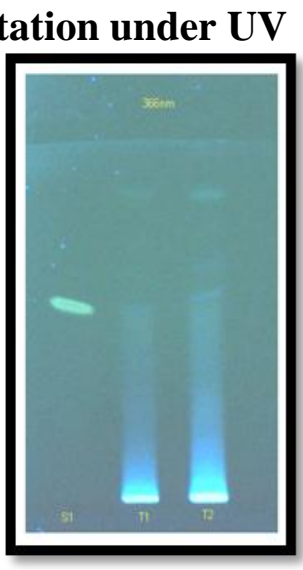

S1 $\quad$ S2 S3 AT 366nm

3D DISPLAY \& 254 nm

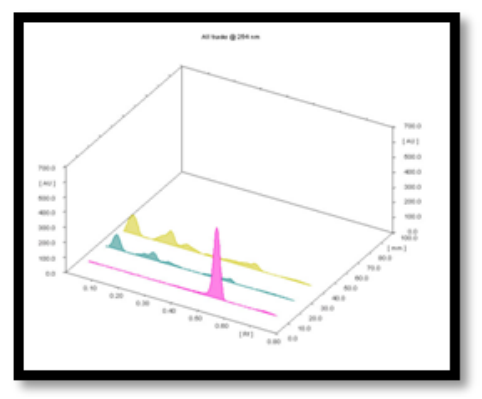

Fig.2 HPTLC Chromatogram for standard

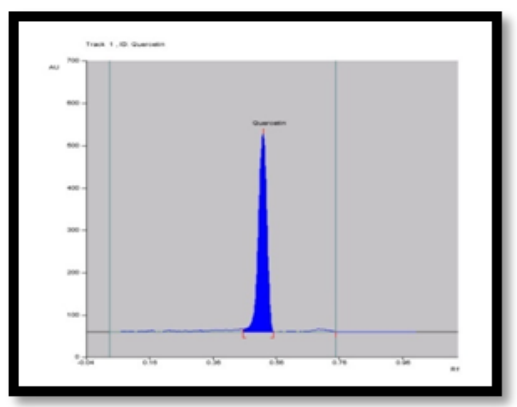


Fig.3 HPTLC Chromatogram for sample ( $5 \mu 1)$

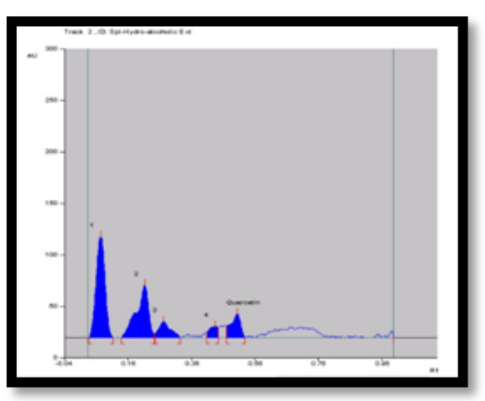

Fig.4 HPTLC Chromatogram for sample $(10 \mu \mathrm{l})$

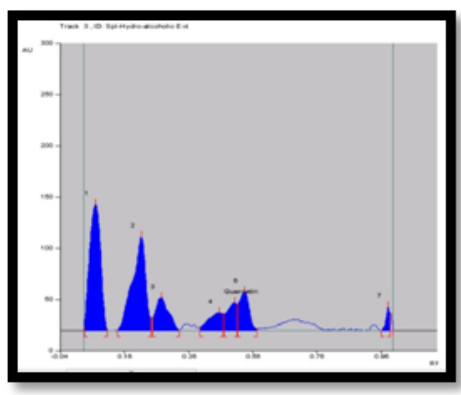

Fig.5

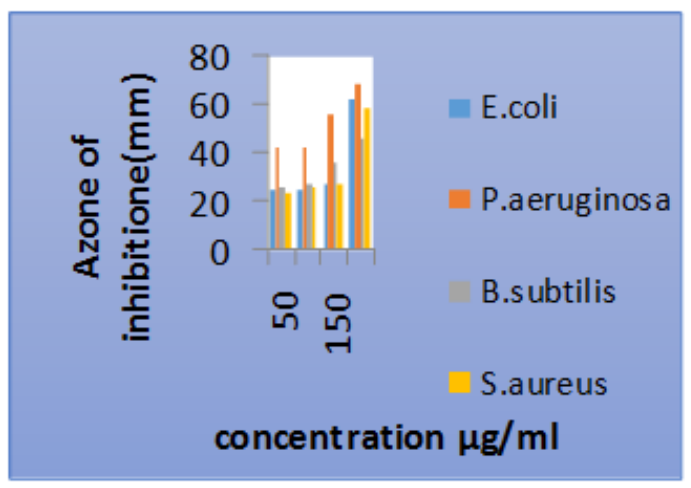

Fig.6

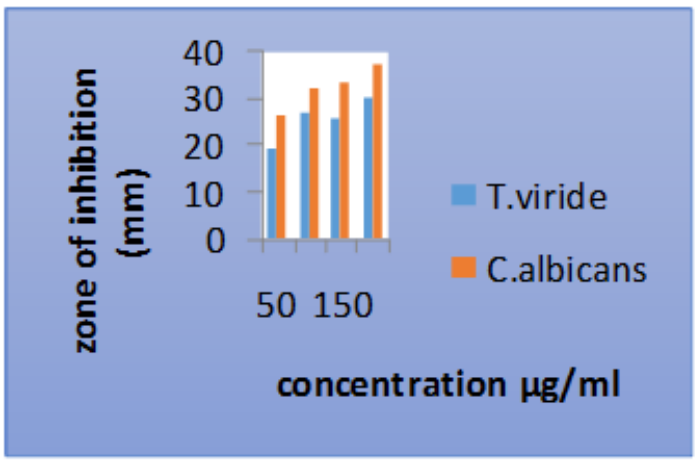


In the present study, antibacterial activity has been performed in the plant extract against bacterial pathogens by disc diffusion method. The maximum zones of inhibition were observed which was ranged between $27 \mathrm{~mm}$ and $56 \mathrm{~mm}$ diameter at the concentration of $150 \mu \mathrm{g}$. Almost all the bacteria were susceptible to plant extract, though in different concentrations which was less than that of standard antibiotic. The result revealed that the aqueous flower extract of Mirabilis Jalapa possessed significant inhibitory activity against Staphylococcus aureus, Pseudomonas aeruginosa, Bacillus subtilis, and E.coli. Antimicrobial activities of the aqueous extract of Mirabilis jalapa have been attributed to the presence of the phytoconstituents (Oladunmoye, 2007). Previous study reported that various leaf extracts of Mirabilis jalapa have been shown to be significantly effective against gram positive and gram negative bacteria (Muthumani et al., 2009).

Medicinal plants represent a rich source of antimicrobial agents (Mahesh and Satish, 2008). Many of the plant materials used in traditional medicine are readily available in rural areas at relatively cheaper price (Mann et al., 2008). Plants produce a great deal of secondary metabolites, many of them with antifungal activity. Well-known examples of these compounds include flavonoids, phenols and phenolic glycosides, unsaturated lactones, sulphur compounds, saponins, cyanogenic glycosides and glucosinolates (Bennett and Wallsgrove, 1994; Osbourne, 1996).

In the present study, antifungal activity of plant extract was performed against pathogenic fungi Trichoderma viride and Candida albicans by disc diffusion method. Among the three different concentration of plant extract, $150 \mu \mathrm{g}$ showed maximum zone of inhibition ranges between 19.5 to $33.5 \mathrm{~mm}$ which was less than that of standard antibiotic amphotericin-B (30 to $37.3 \mathrm{~mm})$. The potential for developing antimicrobials from higher plants appears rewarding as it will lead to the development of a phytomedicine to act against microbes. Plant-based antimicrobials have enormous therapeutic potential as they can serve the purpose with lesser side effects that are often associated with synthetic antimicrobials (Iwu et al., 1999).

In conclusion, the result of the present study showed that the aqueous extract of Mirabilis jalapa flowers exhibited the greatest antimicrobial activity against gram positive, gram negative and fungal species. The study also reports HPTLC analysis of quercetin from flower extract. The overall study, thus, emphasizes the potency of Mirabilis jalapa as a sustainable source of new broad spectrum of antimicrobial products which may be due to the presence of active constituent quercetin. However, further research is required to determine the compound that has contributed to the antimicrobial activity of the extract and its exact mode of action.

\section{References}

Ali, M.S., Yaghmour, R.M., Farida, Y. 1998. Antimicrobial activity of 20 plants used in folkloric medicine in the Palestinian area. J/ Ethanopharmacol.. 60: 258-271.

Ammara, H., Salma R., Farah, D., Shahid, M. 2009. Antimicrobial activity of some plant extracts having hepatoprotective effects. J. Medicinal Plant Res., 3(1): 020-023.

Arora pooja, Annu sindhu, Neeraj, Dilbaghi, Ashok Chaudhary. 2011. Biosensors as innovative tools for the detection of food borne pathogens. Biosensors and Bioeletronics. 28: 1-12.

Barbour, E., Sharif, M.A., Sagherian, V.K., 
and Fibre, A.N. 2004. Screening of selected indigenous plants of Lebanon for antimicrobial activity. $J$. Ethanopharmacol., 93: 1-7.

Bauer, A.W., Kirby, W.M.M., Sherris, J.C. 1966. Antibiotic susceptibility testing by a standardized single disk method. Am. J. Clin. Pathol., 45: 493-496.

Bennett, R.N., Wallsgrove, R.M. 1994. Secondary metabolites in plant defence mechanisms. New phytol., 127: 617-633.

Borges, A., Ferreira, C., Saavedra, M.J., Simões, M. 2013. Antibacterial activity and mode of action of Ferulic and Gallic acids against pathogenic bacteria microbial drug resistance. Microbe Drug Resist., 19(4): 256-265.

Bouamama, H., Noel, T., Villard, J., Benharref, A., Jana, M. 2006. Antimicrobial activities of the leaf of the leaf extract two Moroccan Citrus L. species. J. Ethnopharmacol., 104: 104107.

Cowan, M.M. 1999. Plant products as antimicrobial agents. Clin. Microbiol. rev., 12: 564-82.

Cushnie, T.P.T., Lamb, A.J. 2011. Recent advances in understanding the antibacterial properties of flavonoids. Int. J. Antimicrob Agents, 38(2): 99-107.

Dahanukar, S.A., Kulkarni, R.A., Rege, N.N. 2000. Pharmacology of Medicinal Plants and Natural Products. Indian $J$. Pharmacol., 32: S81-S118.

Griggs, J.K., Manander, H.P., Towers, G.H.N., Talor, R.S.I. 2001. The effects of storage on the biological activity of medicinal plants from Nepal. $J$. Ethnopharmacol., 77: 247-252.

Gupta, N., Lobo, R., Chandrashekhar, K.S., Gupta, D. 2012. Determination of Phenol and flavonoid content from Vateria indica (Linn). Der Pharmacia Lettre, 4(1): 222226.

Harborne, J.B., Mabry, T.J., Mabry, H. 1975. The Flavonoids. Chapman and Hall, ondon: pp. 1204.

Hill, Hidaka, K., Masuda, T., Yamaguchi, H. 1989. Chemical studies on antioxidant mechanism of curcumin analysis of oxidative coupling products from curcumin and linoleate. J. Agri. Food Chem., 49: 2539-2547.

Ibrahim, M.B. 1997. Anti-microbial effects of extract leaf, stem and root bark of Anogeissus leiocarpus on Staphylococcus aureus, Streptococcus pyogenes, Escherichia coli and Proteus vulgaris. $J$. Pharma Devpt, 2: 20-30.

Idu, M., Omogbai, E.K.I., Aghimien, G.E.I., Amaechina, F., Timothy, O., Omonigho, S.E. 2007. Preliminary phytochemistry, antimicrobial properties and acute toxicity of Stachytarpheta jamaicensis (L.) Vahl. Leaves. Trends in Med. Res., 2: 193-198.

Iwu, M.M., Duncan, A.R., Okunji, C.O. 1999. New Antimicrobials of plant origin. In Janick, J. (ed) Perspectives in New crops and New uses. ASHS Press, Alexandria, V.A. pp 457-462

Kiran Kumar, V., Ravi Sankar, N., Ramya, S., Saritha, K., Sahaja, R.V., Reddy, KG., and Naidu, N.V. 2010. Phytochemical screening and antimicrobial activity of leaf extract of Mirabilis jalapa against pathogenic microorganisms. Int. J. Phytomed., 2(4): 402-407.

Koshy, P., Sri, N.A.M., Wirakanain, S. et al. 2009. Antimicrobial activity of some medicinal plants from Malaysia. Am. J. Appl. Sci., 6(8): 1613-1617.

Mahesh, B., Sathish, S. 2009. Antimicrobial activity of some important medicinal plants against plant and human pathogen. World J. Agri. Sci., 4(s): 839-843.

Mamatha, A. 2011. Quantitative HPTLC analysis of andrographolide in Andrographis paniculata obtained from different geographical sources (India). Int. J. Pharma. Sci., 3(2): 42-44.

Mann, A., Banso, A., and Clifford, L.C. 2008. An antifungal property of crude plant extracts from Anogeissus leiocarpus and Terminalia avicennioides. Tanzania J. Health Res., 10(4): 34-35.

Muthumani, P., Devi, P., Meera, R., Kameswar, B., Eswarapriya, B. 2009. In vitro antimicrobial activity of various 
extracts of Mirabilis jalapa leaves. Int. J. Microbiol., 7 (2):120-124.

Okemo, P., Nwanta, W., Chabra S., Fabry, W. 2001. The kill kinetics of Azadirachta indica A. Juss. (Meliaceae) extracts on Staphylococcus aureus, Escherichia coli, Pseudomonas aeruginosa and Candida albicans France J. Sci. Technol., 2: 113118.

Oladunmoye, M.K. 2007. Comparative evaluation of antimicrobial activities of leaf extract of Mirabilis japapa and microbial toxins on some pathogenic bacteria. Trends in Med. Res., 2(2): 108112.

Osbourne, A.E. 1996. Preformed antimicrobial compounds and plant defense against fungal attack. Plant Cell, 8: 1821-1831.

Perez, C., Paul, M., Bazerque, P. 1990. Antibiotic assay by agar well diffusion method. Acta Bio. Med. Exp., 15: 113115.

Pharmacopéè Francaise, $7^{\text {th }}$ edn, Wolter Kluver France, 1965.

Rabe, T., Vanstoden, J. 2000. Isolation of an antimicrobial sesquiterpenoid from Warbugie salutaris. J. Pharmacol., 93: 171-174.

Reich, E., Schibli, A. 2007. High-Performance Thin-Layer Chromatography for the Analysis of Medicinal Plants. Thieme Medical Publishers Inc.; New York, NY: pp. 132-156.

Sachin, U., Rakesh, Patil, P.R., Salunkhe, V.R., Dhabale, P.N., Burade, K.B. 2009. HPTLC method for quantitative determination of quercetin in hydroalcoholic extract of dried flower of Nymphaea stellata wild. Int. J. Chem.
Tech. Res., 1 (4): 931-936.

Salie, F., Eagles, P.F.K., Beng, H.M.L. 1996. Preliminary screening of four south African Asteraceae species. $J$. Ethnopharmacol., 52: 27-33.

Sethi, P.D. 1996. High Performance Thin Layer Chromatography: Quantitative Analysis of Pharmaceutical Formulations, CBS Publishers and Distributers, New Delhi, 10-60.

Sofowora, A. 1982. Medicinal plants and traditional medicine in Africa. John Wiley, Chichester, 179.

Srivastava, M. High-Performance Thin-Layer Chromatography (Hptlc). Springer, Heidelberg Dordrecht London, New York, 2011.

Syed, M.H., Yasmeen, A., Hussain, M.S., Subramanian, N.S., Ramadevi, M. 2013. Preliminary phytochemical screening and HPTLC fingerprinting of leaf extracts of Pisonea aculeata. J. Pharmacognosy Phytochem., 2(1): 36-42.

Vardhana, R. 2008. Direct uses of Medical plants and their identification arup7SONS New Delhi, pp:2

Walid, E., Abd-Allah, Hassan, M., Awad, and Mona, M., Abdel Mohsen. 2015. HPLC Analysis of Quercetin and Antimicrobial Activity of Comparative Methanol Extracts of Shinus molle L. Int. J. Curr. Microbial App. Sci., 4(11): 550558.

Yasunaka, K., Abe, F., Nagayama, A. 2005. Antibacterial activity of crude extracts from Mexican medicinal plants and purified coumarins and xanthenes. $J$. Ethanopharmacol., 97: 293-299.

\section{How to cite this article:}

Kalaivani, K., and Prasanna, G. 2016. HPTLC Finger Print Profile and Evaluation of in vitro Antimicrobial Activity of Mirabilis jalapa L. Flowers. Int.J.Curr.Microbiol.App.Sci. 5(6): 642-653. doi: http://dx.doi.org/10.20546/ijcmas.2016.506.070 